\title{
Euphemisms in 2019 Presidential Election Debates
}

\author{
HENDRI PITRIO PUTRA \\ hendripitrio.2017@student.uny.ac.id \\ PRATOMO WIDODO \\ prat_wid@yahoo.com \\ Applied Linguistics S2 Study Program, Universitas Negeri Yogyakarta \\ Yogyakarta, Indonesia
}

submitted: 30/7/2020 revised: 26/11/2020 accepted: 28/11/2020 DOI: 10.22515/ljbs.v5i2.2656 pages: 123-134

ABSTRACT This research aimed at describing the forms and functions of euphemism in the Presidential and Vice-Presidential Debate of the Republic of Indonesia in 2019. This research also explained the form and function of euphemism that was most dominantlyused and whose speech containing most elements of euphemism. The method used in the research was descriptive qualitative method and content analysis approach. The data sources in this research were videos and transcripts of the Presidential and Vice-Presidential Debate in the first and fifth rounds in 2019. The results of this study revealednine forms of euphemism, namely figurative expression, metaphor, flippancy, circumlocutions, clipping, acronym, abbreviation, one for one substitution, borrowing, and hyperbole. The most dominant euphemism form used was one for One Substitution with the total of 164 or $61.4 \%$. Furthermore, the speech that had the most euphemism was Joko Widodo with the total of 113 euphemisms or $42.3 \%$. Finally, this research also showedfour functions of euphemismas a form of positive imaging, criticizing or insinuating opponents, refining speech, and as a tool for diplomacy.

Keywords: euphemism, debate, presidential election

INTRODUCTION Presidential election to choose the president and vice-president is a democratic party organized by the General Election Commission/Komisi Pemilihan Umum (called KPU) of the Republic of Indonesia as an official institution for election management every five years. This election is very important because this election was chosen directly by the people and carried out simultaneously in all regions of Indonesia. The results of presidential election determine who will be the president and vice president of the Republic of Indonesia for the next five years.

Stated from the official website of the KPU (2019), the 2019 presidential election were followed by two pairs of candidates in which the first candidate pair was Joko Widodo and Ma'ruf Amin and the second candidate pair was Prabowo Subianto and Sandiaga Salahudin Uno. The candidates met in the 2019 presidential and vice-presidential debate before the official election took place on April 17, 2019. During debate, the presidential and vicepresidential candidates argued and viewed the problems that occured in Indonesia. In addition, this debate was an event to convey and explain the vision and mission and work programs of the two pairs of candidates if elected as president and vice president. The debate of president and vicepresident candidate was held five times. For Indonesian people, this debate wasan opportunity to see and assess the candidates' quality directly and transparently. Therefore, the candidate pairs madean effort to get people's sympathy. Even the candidates wereallowed to use the language style or arrange their language as well as possible so that they conveyed the arguments and views in a polite, refined and acceptable manner for the Indonesian community.

The choice and use of the language style used by the candidate pair is called euphemism. Euphemism is an identifying feature that aims to disguise 
intentions that are roughly worded with refined expressions (Fernandez 2014). According to Sutarman (2013) in the form of words or phrases that are considered to be more refined, polite, and safe are expressions with aim atreplacing other expressions that are deemed impolite or believed to give bad effect. Additionally, euphemism is often referred to as taboo words. Taboo is a word that should not be used or a word that is considered not good and taboo in 'polite society' (Fromkin 2005, 476). This means that taboo is a social prohibition not to use words, objects, actions, discussions, or people in which they are considered unwanted or offensive to the community, for example, the topics of sex, death, social status, social work etc.

Therefore, the two candidate pairs were predicted to use euphemism to avoid unpleasant situations as a result of mentioning irreverent words. For this reason, theywere predicted to choose more refined and polite words to maintain stability and good social relations in the community. Accordingly, the chosen and used euphemism can be a bridge between the candidate to get the attention of the public.

According to Allan \& Burridge (1991), the forms of euphemism consist of figurative expressions, metaphor, flippancy, remodelling, circumlocutions, clipping, acronym, abbreviations, omission, onefor one substation, general for specific, part for whole euphemism, hyperbole, understatement, jargon, and colloquial. Furthermore, the main function of euphemism is as a means to generate speech, keep secrets, diplomatic tools, educational tools and repellent devices and to obtain peace, tranquillity, welfare, and safety, (Wijana,2008). This is in line with Deng $(2016,543)$ who said that the function of euphemism is to avoid taboos, as a form of polite expression, a concealment of truth, and as a means of humor.

Previously, there have been some researchers on euphemisms, such as the research from Pujaningrat (2001) and Sari (2013) who examine the forms, types, and functions of euphemism found in newspaper; Karam (2011) who investigates how euphemism is used in the political area; as well as Astuti (2016) and Setiawaty \& Wahyudi (2018) who review the forms and functions of euphemisms found in the comment columns on Facebook. From some of the studies above, the researchers have not found any research that directly examines the form and function of euphemism from direct actors. Therefore, it is interesting to analyse and find the differences. Besides, this topic is consideredfascinating because presidential and vice-presidential debate is a national agenda held every five years and the debate also gets enormous attention from Indonesian people and even gets a huge spotlight from the international world.

RESEARCH METHOD The method used in this researchwas a qualitative descriptive method with a contentanalysis approach. The data analysed in qualitative descriptive method is not numerical data (quantitative data) but the data in the form of words (Mahsun 2014). So, the data in this researchwere words or utterances containing euphemism in the Presidential and Vice-Presidential Debate 2019.

There were two data sources in this research. The firstwasvideo downloaded from YouTube channel TVOneNews as the official National TV appointed by the KPU to broadcast the first round of presidential and vicepresidential debates on January 17, 2019. This video lasted 1 hour 43 minutes 57 seconds. The second data source was video of the fifth debate of vicepresidential candidate aired on April 13, 2019. This video lasted for 2 hour 17 
minutes 08 seconds. This video was also downloaded from YouTube channel TVOneNews. These videos were chosenbased on several considerations: (1) The first and fifth debates were debates followed by presidential and vicepresidential candidates. (2) The second, third and fourth debateswere separated debate between the president and the vice-president candidates. (3) The first and fifth debates had the same proportion between presidential and vice-presidential candidates. (4) Time limitations possessed by researcherso that it was not possible to retrieve all data.Data collection was carried out for a month from 1 April 2019 to 28 April 2019.

Correspondingly, the source of data in this research was also in the form of presidential and vice-presidential debate transcripts. For the first debate, transcript was downloaded from the official website of Tirto.id on April 28, 2019. For the fifth debate, the transcript was downloaded from the language.co.id page on April 28, 2019. Moreover, data collection techniques in this research used the refer method with note-taking techniques (Sudaryanto 2015). The researchers listened to the video and read the transcript carefully and thenwrote all the data. In the next step, the data were collected and inserted into the data card so that it became a transcript that had been classified based on the theories of Allan \& Burridge (1991) and Wijana (2008). After that, the data were analysed, interpreted and made a conclusion.

RESULTS AND DISCUSSION

In this research, researchers found 267 euphemism data which consisted of 127 euphemistic data on the first debate of the Indonesian Presidential and Vice-Presidential Candidates on 17 January 2019 and 140 euphemistic data on the fifth debate of the Indonesian Presidential and Vice-Presidential Candidates on 13 April 2019. It was found that each candidate of president and vice-president 2019 used a form of euphemism with differentpercentage. The forms of euphemism found includedfigurative expression, metaphor, flippancy, circumlocutions, clipping, acronym, abbreviation, one for one substitution, borrowing, and hyperbole. In addition, the researchersalso found four functions of euphemism in the Presidential and Vice-PresidentialDebate of 2019 which included functions as a form of positive imaging, criticizing or insinuating political opponents, refining speech, and for diplomacy.

Table 1: Distribution of the Use of Euphemisms by President and Vice President Candidates in 2019

\begin{tabular}{ccc}
\hline \multirow{2}{*}{ Candidate } & \multicolumn{2}{c}{ The Use of Euphemism } \\
\cline { 2 - 3 } & Number & Percentage \\
\hline Joko Widodo (P) & 113 & $42,3 \%$ \\
Ma'ruf Amin (VP) & 33 & $12,4 \%$ \\
Prabowo Subianto (P) & 50 & $18,7 \%$ \\
Sandiaga Uno (VP) & 71 & $26,6 \%$ \\
Total & 267 & $100,0 \%$ \\
\hline
\end{tabular}

Table 1 shows the most used euphemistic by the presidential and vicepresidentialcandidates. It can be seen that presidential candidate number one Joko Widodo had 113 euphemisms or $42.3 \%$. It is followed by vicepresidential candidate number two Sandiaga Salahudin Uno with 71 euphemisms or $26.6 \%$. The third position is occupied by presidential candidate number two Prabowo Subianto with 50 euphemisms or $18.7 \%$. 
Finally, vice-presidential candidate number one Ma'ruf Amin had the least amount of euphemism of 33 or $12.4 \%$.

Table 2: The Distribution of Forms of Euphemisms in the Debate of President and Vice President Candidates in 2019

\begin{tabular}{lcr}
\hline Forms of Euphemism & Frequency & Percentage \\
\hline Figurative expression & 25 & $9,4 \%$ \\
Metaphor & 2 & $0,7 \%$ \\
Flippancy & 11 & $4,1 \%$ \\
Circumlocutions & 11 & $4,1 \%$ \\
Clipping & 1 & $0,4 \%$ \\
Acronym & 9 & $3,4 \%$ \\
Abbreviation & 24 & $9,0 \%$ \\
One-for-one subs/borrowing & 164 & $61,4 \%$ \\
Hyperbole & 20 & $7,5 \%$ \\
& 267 & $100,0 \%$ \\
\hline
\end{tabular}

Table 2 describes the most dominant euphemism form used by two pairs of presidential and vice-presidential candidates of the Republic of Indonesia in the first and second debate in 2019. The most dominant euphemism form used was One for One Substitution which consisted of absorption words, borrowing words, foreign term/ foreign language/ regional language and others. The number of euphemisms used was 164 or $61.4 \%$. This euphemism was above $50 \%$ of the total euphemism that emerged in the 2019 president and vice-presidential debate. Whereas, the least euphemism form used was clipping with 1 euphemism or $0,4 \%$.

Forms and The following are the forms and functions of the euphemisms found in the Functions of Debate of Presidential and Vice-Presidential Candidates in 2019.

Euphemisms

Figurative According to Allan and Burridge (1991) figurative expression is a form of expressions euphemism that is symbolic or figurative.

(1) Hukum tidak tebang pilih, tidak tajam kebawah, tapi tumpul ke atas. Hukum yang menghadirkan kepastian, sehingga bisa membuka peluang ekonomi, menciftakan lapangan kerja. (Sandiaga, in the first debate [I] in 2019)

(Law is not high grading, not sharp down, but blunt up [Law is impartial, which means equality before the law]. Law provides certainty to open up economic opportunities and create jobs).

(2) Supermasi hukum yang baik, melalui reformasi kelembagaan, dan penguatan system manajemen hukum yang baik dan budaya taat hukum yang harus kita perbaiki, dan hukum harus ditegakan tanpapandang bulu. (Jokowi, 1/2019)

(Good law's supremacy, through institutional reform, and strengthening a good legal management system and a law-abiding culture that we must improve, and the law must be enforced without looking at the fur [indiscriminately]).

(3) Kita ketemukan ada perasaan di masyarakat, bahwa kadang-kadang aparat ituberat sebelah. (Prabowo, 1/ 2019)]. 
(We find that there is a view in the community that sometimes the apparatus are biased [siding with one party]).

(4) Penataan regulasi yaitu menghilangkan yang tumpang tindih dan membuat regulasi peraturan yang berkualitas yang menguntungkan rakyat, memudahkan rakyat dan memberikan peluang terhadap investasi pengembangan UKM. (Ma'ruf, I/2019)

(Regulation arrangement, which means eliminating overlaps and making quality regulations that benefit the people, facilitate the society and provide opportunities for Small and Medium Enterprises development investment)

Utterance (1) above contained three forms of figurative euphemism in which the first figurative euphemism was tebang pilih/high grading, the second onewas tajam ke bawah/sharp down, and the third was tumpul ke atas/blunt up. The phrase of tebang pilih/high grading means that anyone from upper, middle, or lower class who commits a crime must be processed by law without exception, so the law has the same position for Indonesian people. The second phrase oftajam ke bawah/sharp down can be interpreted that law enforcers enforce the law not only for lower class or poor people but also for upper class or rich people. This agreed with the third phrase, which was tumpul ke atas/blunt up. This phrase explained the indication that the applicable law was very slow in processing and upholding the perpetrators of crimes committed by rich people. This resulted in public disbelief towards law enforcement in Indonesia. Therefore, the function of euphemism in utterance (1) was as a tool to criticize political opponents.

In utterance (2), there was a form of figurative expression of euphemismthat was pandang bulu/looking at the fur. According to Indonesian Dictionary (called KBBI) (2016) the word of pandang/looking at means long vision, while bulu/the fur means short and soft hair on the human or animal body. However, in utterance (2), the phrase of pandang bulu/looking at the fur meant to see the difference between one party and the other. Therefore, the intention to be conveyed by speakerwas that every crime committed must be dealt explicitly without seeing differences between one party and the other. The parties referred to the lower middle class people (poor) or the upper middle class (rich) people. Thus, the function of euphemism in this speech could be used as a tool for diplomacy.

In utterance (3), the form of euphemism found was beratsebelah/biased. The phrase biased had the same meaning as speech (1) and (2). This phrase could be interpreted as an indication of injustice in law enforcement in Indonesia. This indication showed that there is a law enforcement officer who chooses to one of the parties. The selection of biased phrase judged by speakers was more subtle than the word siding with one. So the function of euphemism in this utterance was as a tool to refine speech.

Furthermore, utterance (4) contained euphemism of tumpang tindih/overlapping. The point of this speech was the existence of overlapping policies or laws. So, it neededarevision and improvement of the law. Therefore the euphemism function in this contextwas diplomatic.

Metaphor Metaphor is a form of euphemism comparing two things that are implicitly different. (Allan \& Burridge 1991) 
(5) Apabila kami diberikan kepercayaan, amanat untuk memimpin bangsa ini, kami akan melakukannya dengan baik dan kami yakin bisa. Mengapa kami yakin karena kami hafidzul ta'lim. (Ma'ruf, V/2019)

(If we are given trust, the mandate to lead this nation, we will do it well and we believe we can. Why are we sure? Because we are hafidzul ta'lim).

(6) Kenapa kami yakin, karena kami adalah qawiyyun amin, kuat dan juga bisa dipercaya. (Ma'ruf, V/2019)

(Why are we sure? Because we are qawiyyun amen, strong and also trustworthy).

Utterances (5) and (6) consisted of two forms of metaphorical euphemism namely hafidzul ta'lim and qawiyun amen. The phrase hafidzul ta'lim is interpreted as a person who has the belief and strength to protect something. The strength is the power to keep the nation in which the speaker understand what is being faced by this nation. Furthermore, the phrase of qawiyun amen has almost the same meaning as the word hafidzul ta'lim which is strong and can be trusted. Strong in this context meant the speakerhad experience to lead a country. The word trusted can be interpreted as someone who has held a certain political position (someone who still in office) or incumbent. Accordingly, it could be concluded that the speakergave image the public that they are strong presidential and vicepresidential candidates who can lead a country. The function of euphemism in these two phrases was to form a positive image.

Flippancy Flippancy is euphemism in the form of the use of meaning outside of statements. (Allan \& Burridge 1991)

(7) Enggak mungkin langsungmembalikan tangan, kemudian bisa membangun kemudian langsung bisa mengekspor, tidak. (Jokowi, $\mathrm{V} / 2019)$

(It is impossible to immediately turn hands, then we can build and then we can directly export, no).

(8) Negeri kita ini sangat kaya raya, Alhamdulillah kempanye delapan bulan lebih di 1550 kunjungan, saya bertemu danmengharu biru. (Sandiaga, $\mathrm{V} / 2019)$

(Our country is very rich, Alhamdulillah I campaigned for more than eight months in 1550 visits, I met and touched blue).

(9) Mereka betul-betul menjadi menjadi tulang punggung dan kami percaya bahwa enterprenership ini bisa didorong lebih baik sebagai penciptaan lapangan kerja. (Sandiaga, V/2019)

(They really become the backbone and we believe that this entrepreneurship can be encouraged better as job creation).

In utterance (7), a form of flippancy euphemism that was found was membalikan tangan/turn hands. This phrase referred to an activity. It could be interpreted that there was a process that must be passed, and an effort to be made. So the speaker confirmed that it was necessary to raise the balance of Indonesia's exports abroad. Utterance (8) contained flippancy euphemism which was mengharu biru/touched blue. In KBBI (2016), this phrase meant making riots (noisy). But in the context of speech,mengharu biru/touched blue meant to describe the atmosphere of sadness in which the atmosphere was related to many people. The atmosphere illustrated the number of people who metthe speaker and told about the problems they face. The function of flippancy euphemism was to criticize political opponents. 
Furthermore, in utterance (9), it was found a form of flippancy euphemism, namely the tulang punggung/backbone. This phrase meant someone who was a mainstay or support in a matter. In this context, mothers were responsible for making a living for the family. Therefore it needed support from the government to provide jobs for them. So, the function of flippancy euphemism in this utterance was to criticize or insinuate political opponents.

Circumlocutions Circumlocutions are the use of several words that are longer and indirect, (Allan \& Burridge 1991, 14).

(10) Kami tidak punya potongan diktator atau otoriter. Kamitidak punya rekam jejak melanggar HAM. Kami tidak punya rekam jejak melakukan kekerasan. Kami juga tidak punya rekam jejak masalah korupsi. (Jokowi, $\mathrm{l} / 2019)$

(We don't have dictatorial or authoritarian personality. We have no track record of violating human rights. We have no a track record of committing violence. We also have no track record of corruption problems].

(11) Sementara kasus yang berdampak kepada masyarakat orang-orang kecil, wong cilik tidak ditangani dengan baik. (Sandiaga, in the first debate, 2019)).

(While cases that affect the middle-lower class community are not handled well)

In utterance (10), researchers found three forms of circumlocution euphemism at once. These were in the form of clause. The three clauses were have no track record of violating human rights. We have no a track record of committing violence. We also have no track record of corruption problems. Of the three clauses, the speakers indirectly explained or clarified themselves clean from criminal records. The function of euphemism in these utterances was to build a positive image and to insinuate political opponents who had been suspected of having criminal past records.

While for utterances (11), there were phrases of wongcilik/the middlelower class community. According to $\mathrm{KBBI}$ (2016) the middle-lower class community could be interpreted as ordinary people or middle-low society. In this utterance the speaker explained that the poor were the people who have the most impact of injustice from law enforcement in Indonesia. The function of efumism in this phrase aimed to criticize political opponents.

Cilipping Clipping is cutting words so that it becomes short or simple. (Allan \& Burridge 1991)

(12) Untuk orang supaya kuat, supaya tidak korup ini yang harus kita bangun penyelesaiannya. (Prabowo, I/ 2019)

(For people to be strong, so that they are not corrupt, we must build a solution).

Utterance (12) contained a form of euphemism, that was corrupt. Word corrupt referred to one's activities. The complete form of the 'corrupt' is 'corruption'. KBBI (2016) said corruption means misappropriation or misuse of state money (companies, organizations, foundations, etc.) for personal or other benefits. In general, the rough form of the corrupt is to misappropriation money. The use of corrupt was considered to be more 
subtle than its complete form or misappropriation money. Thus, the function of euphemism in the word corrupt was as a way to refine speech.

Acronyms Acronym is a short for word in the form of a combination of letters or syllables or other parts written and pronounced as a reasonable word (KBBI, 2016).

(13) Tapi menurut Indonesian Corruption Watch (ICW), partai yang Bapak pimpin termasuk yang terbanyak mencalonkan mantan koruptor atau mantan napi karupsi. (Jokowi, 1/2019)

(But according to ICW, the party that you lead is considered the most nominating former corruptors or former napi [corruptionprisoners]).

(14) Saya seleksi caleg-caleg tersebut. Kalau ada bukti juga silahkan laporkan kepada kami. (Prabowo, I/2019)

(I selected thosecaleg-caleg(legislative candidates). If there is an evidence, please report it to us).

Utterance (13) contained one form of acronym euphemism, that was napi (prisoner). The word prisoner refers to one's status. The complete form of the napi words is narapidana. Based on Article 1 paragraph (7) of Law Number 12 of 1995 concerning Correctional Service, prisoners are convicts who undergo criminal penalties for independence at the Penitentiary. So, prisoners are interpreted as people or convicts who are serving their sentences in the Penal Institution where their independence is lost. Whereas in this context, the former prisoners were people who had already served their sentence in a prison. The function of euphemism in the word of napi is to refine speech while the function was to quip political opponents.

Utterance (14) contained a euphemism acronym, that was caleg-caleg. The complete form of this phrase is calon legislatif. Legislative candidates are those who nominate themselves to become members of the legislature, or candidates for members of the House of Representatives or the Regional People's Representatives Council. The eufimise function in this sentence was diplomatic.

Abbreviations Abbreviation stands for words into several letters. (Allan \& Burridge 1991)

(15) Kita akan lakukan pelatihan-pelatihan, training-training, baik dalam negeri maupun di luar negeri, bagi lulusanSMA, SMK, akademi, perguruan tinggi, maupun korban-koranPHK. (Jokowi, II/2019).

(We will conduct trainings, both domestically and abroad, for graduates of high school, vocational school, academy, tertiary institutions, and victims of $P H K$ [layoffs]).

(16) Masih banyak masyarakat yang mengeluh, dan itu PR kita. (Sandiaga, I/2019)

(There are still many people who complain, and that is our $P R$ (homework).

In utterance (15), there wre three forms of abbreviation euphemism: SMA, $S M K$ and $P H K$. Here researchers focus on the word PHK (layoff). The term PHK stands for Pemutusan Hubungan Kerja (Termination of Employment). Another word for $P H K$ is employee dismissal. The use of the term $P H K$ was considered to be more polite than the complete form or employees dismissal. So the function of this form of euphemism was to refine speech.

Utterance (16) contained the form of euphemism was PR. The word $P R$ was an abbreviation of Pekerjan Rumah. In this context, the speaker defined 
$P R$ as the one's responsibility or task that must be done. The task in question was the welfare of the people. This form of euphemism functioned for diplomacy.

One-for-one One-for-one Substitution or borrowing is one word to replace another word. substitutions (Allan \& Burridge 1991)

(17) Pak Najib mengambil pasir untuk menanam mangrove. Beliau dipresekusi dan dikriminalisasi. (Sandiaga, I/2019)

(Pak Najib takes sand to plant mangroves. He was executed and criminalized).

(18) Saya kira penting membangun budaya masyarakat untuk memberikan penghormatan kepada kelompokdisabilitas, menyamakan perlakuan baik disabilitasmaupun non disabilitas. (Ma'aruf, l/2019).

(I think it is important to build a culture of society to pay respect to disability groups, equating treatment to both disability and nondisability).

(19) Perlu dibangun industry-industri perikanan sebanyak-banyaknya, pengolahan, pengalengan sehingga kita menekspor dalam bentuk barang-barang yang sudah olahan, sudah di packing disini, sudah dilabeling di sini, sudah membangun brand dari sini. (Jokowi, II/2019)

(Need to build as many fishing industries as possible, processing, canning so that we export in the form of processed goods, already packed here, labeled here, have built a brand from here).

(20) Saya setuju hilirisasi, tetapi kenapa bapak tidak melaksanakan sudah, 4,5 tahun. (Prabowo, V/2019)

(I agree to downstreaming, but why you have not implemented, it has been 4,5 years).

Utterance (17) contained euphemism words of executed and criminalized. These two words are absorbed words from foreign languages. The basic form of the word executed is execute. KBBI (2016), execute is arbitrary hunting of a person or a number of residents and is/are hurt, troubled or crushed. So the word executed is a victim of execution. Whereas the word criminalized is a basic form of criminal that means as a process that shows behavior that was not originally considered a criminal event, but is later classified as a criminal event by the community, KBBI (2016). So,criminalizedrefers to victims of criminal acts. The function of euphemism in this context was to criticize political opponents.

In utterance (18), the form of euphemism was disability. The form of euphemism in the word disability refers to disease. It is mentally or physically handicapped. KBBI (2016) defines disabilityas a situation (such as illness or injury) that damages or limits one's mental and physical abilities. Based on the utterance, the speaker intended to provide justice to disability and nondisability. The use of the disabilitywas to refine speech.

Utterance (19) contained three forms of euphemism: packing, labelling and brand. These are foreign language used by speaker. The use of this foreign language is due to the difficulty of finding the equivalent words in Indonesian so that the use of foreign language is considered more familiar than the use of equivalent word. The function of euphemism in this utterance was diplomacy.

Utterance (20) contained a form of euphemism, that was hiliriasai. The word hiliriasasi in this utterance is an industrial process that processes raw 
materials into finished goods. The function of euphemism in this context is to criticize political opponents.

Hyperbole Hyperbole is an excessive expression (Allan \& Burridge 1991). In addition, hyperbole is a kind of language style that contains excessive statements by exaggerating something (Al-Ma'uf 2012).

(21) Jangan kita ini, sering grasak-grusuk menyampaikan sesuatu, misalnya apa jurkamnya pak Probowo, katanya dianiaya muka nya babak belur, kemudian konferensi pers bersama-sama, akhir nya apa yang terjadi operasi plastic. (Jokowi, 1/2019)

(We don't, often grasak-grusuk [acting irregularly] in convey something, for example, what he Mr.Probowo's cameramen said, he was tortured in a babak belur [battered face], then in a press conference, finally it was revealed the fact that it was plastic surgery).

(22) Jangan terus kita akhirnya harus dibulan-bulani dengan harga bahan pokok yang mahal. (Sandiaga, II/2019)

(It doesn't mean, we must be dibulan-bulani [becoming the target or victims] with expensive basic commodities).

(23) Tetapi pada kurtal pertama tahun ini, coba dilihat deficit turun 0.67 miliar dollar, artinya usaha kita mati-matian untuk menekan deficit neraca perdagangan ini bukan main-main. (Jokowi, II/2019)].

(But in the first quarter of this year, you can see a deficit down 0.67 billion dollars, which means that ourdesperate effortsto suppress the deficit of the trade balance is not playful. (Prabowo V/2019)

(24) Flag carrier kita, kebanggan kita, garuda kita, lahirkan dalam perjuangan kita kok kita biarkan morat-marit seperti sekarang saya kira demikian.

(Our flag, our pride, our Garuda, born in our struggle, how come we let it morat-marit [mess] like now).

Utterance (21) contained a form of hyperbolic euphemism ofgrasakgrusuk/acting irregularly. This form of euphemism refers to more exaggeration events or conditions. Conditions in which a person acts irregularly and starts to disturb of others's peace.

In utterance (22), there was a form of hyperbolic euphemism in the words of dibulan-bulani (becoming the target or victim). The form of euphemism has the same equivalent word as used. In this context, the speaker described the condition of the people who were victims of the expensive prices of basic commodities.

Utterance (23) contained a form of hyperbolic euphemism of desperate. This phrase referred to an activity of someone who was struggling very hard to reduce the trade balance deficit so that it dropped to $0.67 \%$.

Finally, in utterance (24), there was a form of euphemism in morat-marit (mess) word. This phrase refers to irregular conditions. The context of thismessy phrase illustrated that the condition of a particular State-owned Enterprise, Garuda Indonesia, was in a condition that was difficult to become a good management and financial fix. Of the three utterances, utterance (21), (22) and (24) served to criticize political opponents. While for speech (23) it functioed to build a positive image.

CONCLUSION From all of data analyses that were taken from YouTube channel TVOne News as the official National TV appointed by the KPU to broadcast the debates of presidential and vice-presidential 2019, the researcher found nine forms of 
euphemism based on theory proposed by Allan-Burridge. Those forms are figurative expression, metaphor, flippancy, circumlocutions, clipping, acronym, abbreviation, one for one substitution, borrowing, and hyperbole.

The most dominant euphemism form used in the debate of Presidential and Vice-Presidential Candidates is one for one substitution, with a total of 164 or $61.4 \%$. Meanwhile, the least euphemism form used is Clipping with 1 euphemism or $0,4 \%$. The most dominant user of euphemism is Presidential Candidate number one, Joko Widodo, with 113 euphemisms or $42.3 \%$. While, the least dominant useris Vice-Presidential Candidate number one Ma'ruf Amin with a number of euphemism of 33 or $12.4 \%$.

Moreover, the euphemism function found in this study is a means for refining speech, for building positive images in front of the public/sociaty, for diplomacy, and for criticizing/ insinuating political opponents during debates.

ACKNOWLEDGEMENT The researcher would like to extend immense gratitude to LPDP Scholarship for the funding of this small research without which this research may not be possible. and special to my lecturers and all my friends who review this research and try to give valuable suggestions.

REFERENCES

Allan, Keith \& Burridge. 1991. Euphemism \& Dysphemism Language Used as Shield and Weapon. Oxford: Oxford University

Astuti, AY. 2016. Euphemism by the Proponents of Presidential Candidates 2014 in Facebook Account: Sociopragmatic Perspective. (Thesis). Padang: Universitas Andalas

Al-Ma'ruf, Ali Imron. 2012. Stilistika: Teori, Metode, dan Aplikasi Pengkajian Estetika Bahasa. Surakarta: Cakra Books

Deng, Fei. 2016. "An Analysis of Phonetic Formation in English Euphemism". Journal of Language Teaching and Research, 7 (3): 542-547

Fernadez, EC. 2014. "Euphemisms and Political Discourse in the British Regional Press". Brno Studies in English, 40 (1): 5-26

Fromkin, Victoria. 2005. An Introduction to Language. New York: Thompson Corporation

Kamus Besar Bahasa Indonesia (Edisi Kelima). 2016. Jakarta: Badan Pengembangan dan Pembinaan Bahasa, Kementrian Pendidikan dan Kebudayaan Republik Indonesia

Karam, Savo. 2011. "Truths and Euphemisms: How Euphemisms are Used in the Political Arena". 3L: Languange, Linguistics, Literature the Southeast Asian Journal of Language Studies. 17 (1)

Mahsun, MS. 2014. Metode Penelitian Bahasa Metode Penelitian Bahasa: Tahapan Strategi Metode dan Tekniknya. Jakarta: Raja Grafindo Persada

Pujaningrat, S. 2001. "An Analysis of euphemisms in Rubric World of The Jakarta Post of December 2010 Edition". (Thesis). Jakarta: UIN Syarif Hidayatullah

Riandi, Oskar. 2019. "Transkrip Lengkap Debat Kelima Capres-Cawapres RI Tanggal 13 April 2019". Bahasakita.co.id. Retrieved April 28, 2019, from https://www. slideshare.net/SabarArtiyono/transkrip-lengkap-debat-pilpres-kelima-oleh-www bahasakitaco

Saputri, Maya. 2019. "Transkrip Lengkap Debat Perdana Pilpres 2019 Segmen Satu". Tirto.id. Retrieved April 28, 2019 from https://tirto.id/transkrip-lengkap-debatperdana-pilpres-2019-segmen-satu-deEY

Saputri, Maya. 2019. "Transkrip Lengkap Debat Perdana Pilpres 2019 Segmen Dua". Tirto.id. Retrieved April 28, 2019 from https://tirto.id/transkrip-lengkap-debatperdana-pilpres-2019-segmen-dua-deE 1

Saputri, Maya. 2019. "Transkrip Lengkap Debat Perdana Pilpres 2019 Segmen Tiga". Tirto.id. Retrieved April 28, 2019 from https://tirto.id/transkrip-lengkap-debatperdana-pilpres-2019-segmen-tiga-deE3

Saputri, Maya. 2019. "Transkrip Lengkap Debat Perdana Pilpres 2019 Segmen Empat". Tirto.id. Retrieved April 28, 2019 from https://tirto.id/transkrip-lengkap-debatperdana-pilpres-2019-segmen-empat-deE5 
Saputri, Maya. 2019. "Transkrip Lengkap Debat Perdana Pilpres 2019 Segmen Lima". Tirto.id. Retrieved April 28, 2019 from https://tirto.id/transkrip-lengkap-debatperdana-pilpres-2019-segmen-lima-deE8

Sari, Dita. 2013. "Euphemism found in Opinion Column of The Jakarta Post News Paper". English Language and Literature E-Journal: 77-82

Setiawaty, R \& Wahyudi, A. 2018. "Bentuk Dan Fungsi Eufemisme Dalam Komentar Akun Facebook Presiden Joko Widodo Sebagai Bahan Ajar Bahasa Indonesia". Proceedings of the 7th University Research Colloquium. Surakarta, Februari 2019: 8899

Sudaryanto. 2015. Metode dan Aneka Teknik Analisis Bahasa: Pengantar Penelitian Wahana Kebudayaan Secara Linguistik. Yogyakarta: Sanata Dharma Universitas Press

Sutarman. 2013. Tabu Bahasa dan Eufemisme. Surakarta: Yuma Pustaka.

Wijana, I Dewa Putu \& Mohammad Rohmadi. 2008. Semantik: Teori dan Analisis. Surakarta: Yuma Pustaka

Youtube. 2019. "[FULL] Debat Capres dan Cawapres Pilpres 2019". Video File TV One News. Retrieved April 28, 2019 from https://www.youtube.com/watch? $v=\mid C e U C$ 8 tacQM\&t=5110s

Youtube. 2019. "[FULL] Debat Kelima Capres-Cawapres Pemilu 2019". Video File TV one News. Retrieved April 28, 2019 from https://www.youtube.com/watch? $v=G c g$ 121WE2CE

\section{Copyright (c 2020 Leksema: Jurnal Bahasa dan Sastra}

